\title{
Pemberdayaan Pemuda Karang Taruna Dalam Membangun Desa Wisata Melalui Pelatihan English For Guiding
}

\author{
Elfirahmi Thamrin ${ }^{(1)}$, Prilla Lukis Wediyantoro(2), Suatmo Pantja Putra ${ }^{(3)}$ \\ ${ }^{1,2,3}$ Dosen Prodi D3 Bahasa Inggris, Universitas Merdeka Malang \\ Email: ${ }^{1}$ elfirahmi.thamrin@unmer.ac.id, ${ }^{2}$ prillawediyantoro@unmer.ac.id, \\ ${ }^{3}$ suatmo.panca@unmer.ac.id \\ DOI: https://doi.org/10.28926/riset_konseptual.v2i4.70
}

\begin{abstract}
ABSTRAK
Desa Mulyorejo Kecamatan Ngantang merupakan satu dari 13 desa wisata yang dikembangan di Kabupaten Malang. Desa ini memiliki potensi wisata yang tinggi diantaranya view alam yang sangat indah dan lokasinya berdekatan dengan destinasi wisata yang sudah tekenal sebelumnya yaitu Bendungan Selorejo. Terlebih lagi, posisi Desa Mulyorejo terletak pada jalur utama yang menghubungkan Malang dengan kota-kota lain seperti Kediri, Jombang, dan sebagainya, serta merupakan tempat transit baik turis lokal maupun asing. Namun demikian, karena rendahnya tingkat pendidikan termasuk kemampuan berbahasa Inggris, masyarakat belum bisa mengoptimalkan Desa Mulyorejo sebagai desa wisata. Tujuan dari Program Pengembangan Desa Mitra (PPDM) ini adalah untuk memberikan kesadaran kepada pemuda karang taruna akan pentingnya pendidikan terutama Bahasa Inggris dan memberikan pelatihan English for Guiding kepada tiga kelompok karang taruna. Metode pelaksanaan program ini mengadaptasi pola pelaksanaan penelitian tindakan (action research) yang terdiri dari empat tahapan yaitu persiapan, pelaksanaan, observasi, dan refleksi. Hasil dari program PPDM ini adalah masyarakat lebih sadar pentingnya pendidikan dan kepariwisataan dalam mengembangkan desa wisata Mulyorejo serta $77,78 \%$ anggota karang taruna yang diberi pelatihan English for Guiding bisa menyapa turis dan menjelaskan lokasi wisata di Desa Mulyorejo dalam Bahasa Inggris.
\end{abstract}

Kata kunci: desa wisata, potensi wisata, karang taruna, english for guiding

\section{PENDAHULUAN}

Desa dan masyarakat pedesaan merupakan salah satu unsur penting dalam pembangunan karena sumbangsihnya dalam menciptakan stabilitas nasional. Selain itu, desa sendiri berperan dalam menyimpan kekayaan alam (SDA) yang melimpah seperti beras, sayur-mayur, daiging dan ikan. Masyarakat desa juga merupakan sumber tenaga kasar yang sangat dibutuhkan dalam berbagai proyek pembangunan infrastruktur. Oleh karena itu, pembangunan desa dituangkan dalam Undang-Undang.

Mantan Menteri Dalam Negeri Gamawan Fauzi dalam Keterangan Pemerintah pada tanggal 2 April 2012 mengatakan bahwa berdasarkan Undang-Undang desa akan diangkat pada posisi yang terhormat dalam ketatanegaraan Republik Indonesia. Pengaturan desa akan menentukan format desa yang tepat sesuai dengan konteks keragaman lokal dan dalam Undang_Undang desa tersebut juga menyatakan bahwa desa adalah subjek pemerintahan dan pembangunan yang benar-benar berangkat dari bawah (bottom up).

Dengan menyadari pentingnya peranan desa, maka pembangunan desa adalah kewajiban sehingga diterbitkannlah Undang-Undang DesaNo. 6 Tahun 2014.

Salah satu hal yang dilakukan Program Diploma 3 Bahasa Inggris Universitas Merdeka Malang adalah melaksanakan pengabdian kepada masyarakat sebagai bentuk keikut sertaan dalam membangun desa, seperti yang tertuang dalam Tri Dharma Perguruan Tinggi yang meliputi pengajaran, penelitian, dan pengabdian kepada masyarakat. 
Pengabdian kepada masyarakat dalam bentuk Program Pengembangan Desa Mitra (PPDM) ini dilakukan di Desa Mulyorejo, Kecamatan Ngantang, Kabupaten Malang.

Desa Mulyorejo adalah salah satu dari 13 desa wisata di Kabupaten Malang. Desa ini memiliki view alam yang sangat indah. Selain itu, salah satu Kawasan wisata yang sudah terkenal sebelumnya yaitu Bendungan Selorejo juga melewati desa ini. Oleh karena itu, Desa Mulyorejo perlu dikembangkan secara optimal sebagai desa wisata yang bisa meningkatkan taraf hidup masyarakatnya.

Secara demografis, Desa Mulyorejo memiliki 4.634 penduduk yang tersebar di lima dusun dengan mata pencaharian mayoritas penduduk (26,99\% (1.251 orang)) adalah buruh tani. Sedangkan dilihat dari Sumber Daya Manusia (SDM), 21,28\% (986 orang) penduduk adalah lulusan Sekolah Dasar atau sederajat.

Hadiwidjojo (2012) menyebutkan bahwa karakteristik desa wisata adalah memiliki aksesibilitas yang baik; memiliki obyek-objek menarik berupa alam, seni budaya, legenda, makanan lokal, dan sebagainya; mendapat dukungan penuh dari aparat desa dan ada wisatawan yang berkunjung; keamanan desa terjamin; tersedia akomodasi, telekomunikasi, dan tenaga kerja yang memadai; beriklim sejuk atau dingin; dan berhubungan dengan objek wisata lain yang sudah dikenal oleh masyarakat luas.

Berdasarkan fakta di lapangan dan teori tentang karakteristik desa wisata yang sudah disebutkan di atas, sebenarnya Desa Mulyorejo sudah memiliki potensi untuk menjadi desa wisata yang bisa dikembangkan.

Lokasi Desa Mulyorejo terletak di wilayah Kecamatan Ngantang yang berudara sejuk dan terletak pada jalur utama yang menghubungkan antara Malang dengan kota-kota lain seperti Kediri, Jombang, dan sebagainya. Desa Mulyorejo juga merupakan tempat transit baik turis lokal maupun turis asing yang akan menuju Jogja dan sebagainya. Desa ini juga dalam konsisi aman dan dekat dengan objek wisata air yang sudah terkenal yaitu bendungan Selorejo.

Namun demikian, untuk menjadikan Desa Mulyorejo sebagai desa wisata yang optimal masih banyak yang harus dipersiapkan. Berdasarkan gambaran kondisi Desa Mulyorejo yang sudah disebutkan sebelumnya, terlihat bahwa rendahnya kualitas Sumber Daya Manusia (SDM) adalah faktor permasalahan utama yang perlu diatasi. Permasalahan terkait SDM ini meliputi rendahnya tingkat pendidikan sehingga kesadaran masyarakat untuk mengembangkan desa wisata belum optimal.

Oleh karena itu, dengan memperhatikan pentingnya sektor kepariwisataan bagi Desa Mulyorejo, warga desa haruslah memiliki kemampuan Bahasa Inggris khususnya English for tourism sehingga dengan itu masyarakat bisa menarik turis terutama turis asing untuk tidak hanya lewat desa ini melainkan bisa juga bisa diajak berkeliling di desa ini untuk menikmati suguhan pemandangan alam dan budaya yang ada sehingga masyarakat desa mendapatkan income tambahan serta bisa menciptakan lapangan pekerjaan baru yaitu tour guide.

Pemberdayaan berasal daya yang artinya kemampuan melakukan sesuatu atau kemampuan bertindak. Sedangkan pemberdayaan merupakan suatu proses, cara, perbuatan memberdaya. Sedangkan inti pemberdayaan itu menurut Kartasasmita (1996) adalah langkah-langkah yang dilakukan agar mampu berkembang dengan memberikan dorongan, motovasi, membangkitkan kesadaran akan potensi yang dimiliki. Kurnia (2012) juga menyebutkan bahwa pemberdayaan masyarakat merupakan proses membangun manusia atau masyarakat melalui tiga cara yaitu pengembangan kemampuan masyarakat, perubahan perilaku masyarakat, dan pengorganisasian masyarakat. Lebih lanjut dia menyebutkan tujuan akhir dari pemberdayaan adalah membentuk masyarakat yang mandiri.

Lima prinsip dasar dalam pemberdayaan masyarakat yang dapat dilakukan agar terbentuknya masyarakat yang mandiri menurut Kurnia (2012) adalah dengan cara membangkitkan kesadaran, setelah itu memberikan pelatihan, dan pengorganisasian. Pengorganisasian dilakukan dengan tujuan agar semua hal 
Vol. 2 No. 4, Oktober 2018;

dikerjakan secara teratur dengan adanya pembagian tugas untuk setiap individu yang harus bertanggungjawab terhadap pelaksanaan tugas masing-masing. Dengan terbentuknya organisasi selanjutnya dilakukan pengembangan kekuatan dan terakhir membangun dinamika. Maksudnya masyarakat berperan dalam mengambil keputusan, serta melaksanakan program-program yang telah diputuskan oleh organisasi masyarakat itu sendiri.

Pariwisata secara bahasa berarti segala hal yang berhubungan dengan perjalanan untuk rekreasi atau pelancongan. Adapun pariwisata menurut Suwantoro (2004) adalah suatu proses kepergian semetara dari seseorang atau lebih menuju tempat lain di luar tempat tinggalnya. Sedangkan di dalam Undang-Undang No 10 Tahun 2009 dan Peraturan Presiden (Perpres) No 40 tahun 2017 disebutkan bahwa kepariwisataan (tourism) adalah keseluruhan kegiatan yang terkait dengan pariwisata dan bersifat multidimensi serta multidisiplin yang muncul sebagai wujud kebutuhan setiap orang dan negara serta interaksi antara wisatawan dan masyarakat setempat, sesama wisatawan, Pemerintah, Pemerintah Daerah, dan pengusaha. Sehingga dapat disimpulkan bahwa pariwisata dan kepariwisataan merupakan semua aktivitas yang berkaitan dengan perjalanan ke tempat lain dengan penyediaan segala hal terkait seperti transportasis, akomodasi, dan atraksi yang bersifat multidimensi dan berbagai pihak.

Host and Guest (1989) dalam Kusumanigrum (2009:3) mengklasifikasikan jenis pariwisata sebagai berikut (1) Pariwisata Etnik (Etnhic Tourism), yaitu perjalanan untuk mengamati perwujudan kebudayaan dan gaya hidup masyarakat yang menarik, (2) Pariwisata Budaya (Culture Tourism), yaitu perjalanan untuk meresapi atau untuk mengalami gaya hidup yang telah hilang dari ingatan manusia, (2) Pariwisata Rekreasi (Recreation Tourism), yaitu kegiatan pariwisata yang berkisar pada olahraga, menghilangkan ketegangan dan melakukan kontak social dengan suasana santai, (3) Pariwisata Alam (Eco Tourism), yaitu perjalanan kesuatu tempat yang relative masih asli atau belum tercemar, dengan tujuan untuk mepelajari, mengagumi, menikmati pemandangan, tumbuhan, dan binatang liar serta perwujudan budaya yang ada atau pernah ada di tempat tersebut, (4) Pariwisata Kota (City Tourism), yaitu perjalanan dalam suatu kota untuk menikmati pemandangan, tumbuhan dan binatang liar serta perwujudan budaya yang ada atau pernah ada di tempat tersebut, (5) Resort City, yaitu kota atau perkampungan yang mempunyai tumpuan kehidupan pada persediaan sarana atau prasarana wisata yaitu penginapan, restoran, olahraga, hiburan dan persediaan tamasya lainnya. (6) Pariwisata Agro (Agro Tourism yang terdiri dari Rural Tourism atau Farm Tourism) yaitu merupakan perjalanan untuk meresapi dan mempelajari kegiatan pertanian, perkebunan, peternakan, kehutanan. Jenis wisata ini bertujuan mengajak wisatawan memikirikan alam dan kelestariannya.

Saat ini objek wisata tidak hanya ditemui di perkotaan. Namun desa pun dapat menjadi tempat wisata yang disebut desa wisata. Desa wisata merupakan suatu wilayah pedesaan yang menawarkan keseluruhan suasana yang mencerminkan keaslian desa, baik dari segi kehidupan sosial budaya, adat istiadat, aktifitas keseharian, arsitektur bangunan, dan struktur tata ruang desa, serta potensi yang mampu dikembangkan sebagai daya tarik wisata, misalnya: atraksi, makanan dan minuman, cinderamata, penginapan, dan kebutuhan wisata lainnya (Fandeli, 2002).

Keberadaan desa wisata perlu dikembangkan agar tidak hanya sekedar label namun memberikan nilai ekonomis pada desa tersebut. Pertama kali yang dilakukan adalah melakukan survey untuk menggali lebih dalam tentang ketiga karang taruna ini baik dari segi keunggulan maupun kekurangan. Berdasarkan hasil survey terhadap tiga karang taruna yang akan dibina yaitu Karang Taruna Karya Muda dari Dusun Maron, Karang Taruna Dusun Sukoanyar, dan Karang Taruna Desa Mulyorejo diperoleh data bahwa Karang Taruna Karya Muda Dusun Maron adalah karang taruna yang paling aktif dalam berbagai kegiatan di Desa Mulyorejo bahkan sudah memiliki blog dan akun Facebook. Selain itu, karang taruna ini sudah memiliki visi dan misi yang jelas serta kegiatan yang jelas yaitu kegiatan rutin dan insidentil. Kegiatan rutin karang taruna ini 
diantaranya kegiatan gantangan burung kicau dan kegiatan insidentil mereka adalah seperti lomba jalan santai, penggalangan dan penyaluran dana untuk anak yatim piatu, dan sebagainya. Selain itu, karang taruna ini juga sudah memiliki leaflet yang berisi moto dan keunggulan yang dimiliki Dusun Maron. Sedikit berbeda, Karang Taruna Dusun Sukoanyar belum memiliki kegiatan rutinan karena kebanyaan pemudanya sibuk bekerja di pa pabrik sehingga karang taruna ini pasif. Terlebih lagi, jarak antara Dusun Sukoanyar dengan Balai Desa cukup jauh, sehingga terjadi kurangnya koordinasi antara pemerintah desa dengan perangkat dan kelompok yang ada di dusun termasuk dengan karang tarunanya. Karang Taruna Desa Mulyorejo juga tidak jauh berbeda dengan Karang Taruna Dusun Sukoanyar. Walaupun Karang Taruna ini merupakan karang taruna induk yang ada di Desa Mulyorejo dan merupakan gabungan beberapa Karang Taruna di Desa Mulyorejo, namun tidak ada kejelasan kepengurusannya, bahkan berdasarkan interview dengan ketua Karang Taruna Dusun Maron, karang Taruna Desa Mulyorejo tidak memiliki ketua.

Dari segi tingkat pendidikan, anggota ketiga karang taruna ini memiliki latar belakang yang beragam mulai dari tamatan Sekolah Dasar hingga S1 walaupun jumlahnya sangat sedikit. Dengan keberagaman tangkat pendidikan ini, pada saat banyak turis terutama turis asing yang singgah di rest area atau sekedar mengambil foto pemandangan di Desa Mulyorejo, rata-rata mereka ingin mengajak para turis asing tersebut untuk mengeksplor Desa Mulyorejo degan tujuan utama menambah pendapatan, namun mereka tidak percaya diri bahkan untuk hanya sekedar menyapa karena kurangnya kemampuan Bahasa Inggris.

Dalam survey ini, selain menggali apa kegiatan karang taruna dan latar belakang pendidikan, pengabdi juga menggali apa saja yang ada di Desa Mulyorejo yang memiliki potensi untuk dijadikan destinasi wisata yang menarik. Dalam hal ini, anggota karang taruna memilih tiga tempat yang menurut mereka potensial, yaitu budidaya anggrek di Dusun Kaweden, budidaya jamur tiram yang ada di Dusun Kambal, serta lokasi akan dibangunnya Jembatan Naga, jembatan bambu yang menghubungkan Desa Mulyorejo dengan Waduk Selorejo yang diharapkan akan menjadi ikon desa nantinya.

Berdasarkan temuan seperti yang disebutkan di atas, pengabdi memberikan beberapa solusi untuk memecahkan permasalahan yang terjadi di desa mitra yaitu: (1) Memberikan penyuluhan tentang pentingnya pendidikan dan pariwisata dalam mengembangkan desa wisata. (2) Memberikan pelatihan English for Guiding khususnya pada Karang Taruna Dusun Maron yang bernama Karang Taruna Karya Muda, Karang Taruna Dusun Sukoanyar, dan Karang Taruna Desa Mulyorejo.

\section{METODE}

Adapun metode yang digunakan untuk mengatasi permasalahan permasalahan desa mitra ini adalah dengan mengadaptasi pola pelaksanaan penelitian tindakan (action research). Menurut Latief (2012:144) ada empat tahapan dalam penelitian tidakan yaitu planning (perencanaan), acting (pelaksanaan), observing (observasi), dan reflecting (refleksi). Oleh karena itu, pengabdi juga melakukan empat tahapan ini dengan didahului oleh survey pendahuluan (preliminary study).

\section{Perencanaan}

Tahapan perencanaan adalah mengembangkan strategi yang akan digunakan untuk menyelesaikan permasalahan. Dalam hal ini adalah masalah pendidikan khususnya kemampuan Bahasa Inggris.

Dalam tahapan perencanaan ini, yang pertama dilakukan pengabdi adalah menentukan subjek yaitu 30 orang anggota dari tiga karang taruna yang ada di Desa Mulyorejo. Kemudian, pengabdi menyiapkan modul pelatihan English for Guiding, dimana modul tersebut berisi tentang kegiatan guiding yang disesuaikan dengan kondisi Desa Mulyorejo, khususnya lokasi-lokasi yang dipilih oleh anggota karang 
taruna ditambah dengan hal-hal yang perlu berkaitan dengan guiding seperti welcoming speech, showing places of interest, explaining rules, explaining safety, explaining etiquette dan closing trip. Pelatihan ini sendiri dilakukan sebanyak 9 kali pertemuan. Dalam pelatihan ini, pengabdi menggunakan metode ceramah, tanya jawab, drilling, dan praktek lapangan.

Adapun prosedur pelaksanaan pelatihan ini adalah sebagai berikut. Pertama, pengabdi menggunakan metode ceramah dan tanya jawab untuk memberikan gambaran umum tentang apa yang akan dilakukan, serta vocabulary and pronunciation drilling kemudian diikuti oleh praktek guiding. Kegiatan ini dilakukan di balai pertemuan Desa Mulyorejo. Setelah masyarakat mulai lancar dalam mempraktekan materi guiding, pelatihan tidak lagi di lakukan di balai pertemuan, melainkan langsung dibawa ke destinasi wisata yang dianggap menonjol di Desa Mulyorejo seperti lokasi budidaya anggrek, budidaya jamur tiram dan juga lokasi akan dibangunnya Jembatan Naga. Di tempat-tempat tersebut, anggota karang taruna yang dilatih tidak lagi hanya membaca teks guiding yang diberikan pengabdi, tetapi juga praktek langsung di lapangan.

Setelah menyiapkan bahan modul pelatihaan dan prosedur pelaksanaan program, pengabdi menentukan criteria of success. Berdasarkan tingkat pendidikan anggota karang taruna dan kemampuan Bahasa Inggris mereka, pengabdi menentukan bahwa program pengabdian ini akan dianggap berhasil jika pemuda dan masyarakat menyadari pentingnya pendidikan formal dan ketrampilan serta $75 \%$ anggota karang taruna yang mengikuti program ini mampu berkomunikasi dengan menggunakan Bahasa Inggris dalam hal menyapa turis dan menjelaskan lokasi wisata di daerahnya. Selanjutya, pengabdi juga menentukan instrumen yaitu berupa praktek guiding di lokasi yang dipilih serta catatan lapangan.

\section{Pelaksanaan}

Pelaksanaan adalah implementasi strategi yang telah direncanakan sebelumnya yaitu mengadakan penyuluhan dan pelatihan English for Guiding.

\section{Observasi}

Observasi dilakukan pada saat proses pelaksanaan program ini menggunakan instrumen catatan lapangan. Pada tahap ini, pengabdi merekam hal-hal yang menunjukkan progress mayarakat dalam menyerap materi pelatihan, kendalakendala, dan kelemahan yang muncul dalam pelaksanaan program ini.

\section{Refleksi}

Refleksi merupakan bagian yang penting dalam tahapan ini. Setelah merekam data, pengabdi menganalisa data yang diperoleh dan membandingkan dengan criteria of success untuk mengetahui seberapa berhasil strategi yang diterapkan.

\section{HASIL \\ Penyuluhan}

Kegiatan ini dilakukan pada tanggal 17 Maret 2018. Dalam penyuluhan ini, anggota karang taruna mendapatkan informasi tentang posisi pariwisata Indonesia di mata dunia, bagaimana cara mengidentifikasi produk-produk desa yang memiliki nilai jual antara lain something to see (apa yang bisa dilihat oleh turis), something to buy (apa yang bisa dibeli oleh turis), dan something to do (apa yang bisa dilakukan turis di Desa Mulyorejo), bagaimana mengemas produk-produk yang telah diidentifikasi sehingga memiliki nilai jual yang tinggi termasuk branding dan penetapan harga, serta bagaimana cara .membangun saluran pemasaran sehingga produk-produk wisata unggulan yang ada di Desa Mulyorejo bisa dikenal baik nasional maupun internasional yang bisa menarik turis sehingga bisa meningkatkan taraf hidup masyarakat Desa Mulyorejo. 


\section{Pelatihan English for Guiding}

Selesai memberikan penyuluhan, pengabdi memberikan pelatihan Bahasa Inggris khususnya English for Tourism sebanyak 9 kali mulai tanggal 24 Maret 2018 hingga 19 Mei 2018. Materi pelatihan ini mencakup welcoming speech, showing places of interest, explaining rules, explaining safety, explaining etiquette dan closing trip.

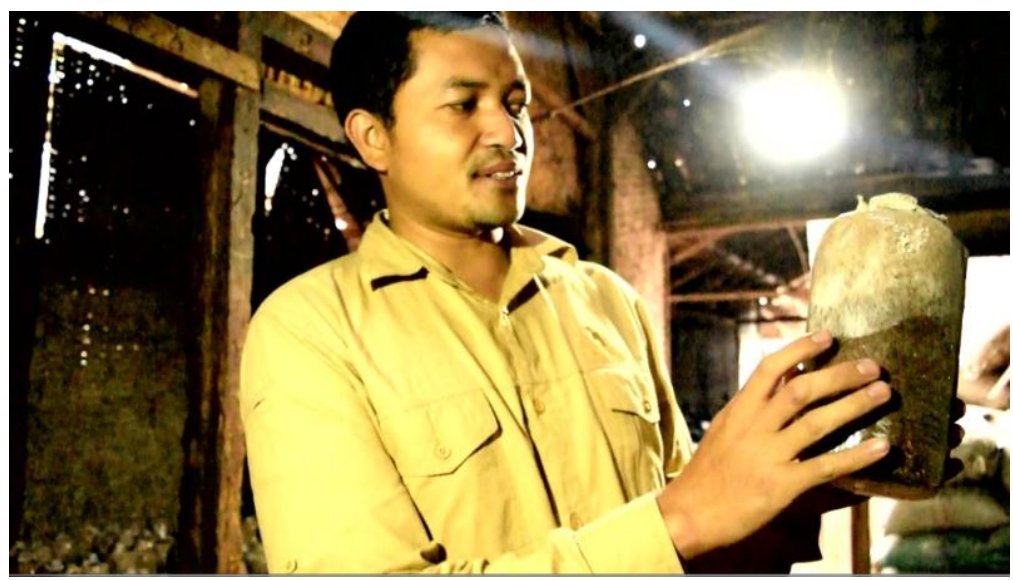

\section{Gambar 1. Anggota karang taruna menjelaskan proses pembibitan Jamur tiram dalam Bahasa Inggris.}

\section{PEMBAHASAN}

Pada materi welcoming speech, anggota karang taruna dilatih untuk bisa menyambut turis asing dengan berbagai cara yang baik dan menarik. Pada materi showing places of interest masyarakat dilatih untuk menjelaskan tiga destinasi wisata yang mereka pilih yaitu budidaya anggrek yang ada di Dusun Kaweden, budidaya jamur tiram yang ada di Dusun Kambal, serta lokasi akan dibangunnya Jembatan Naga, jembatan bambu yang menghubungkan Desa Mulyorejo dengan Waduk Selorejo yang diharapkan akan menjadi ikon desa. Setelah mereka memilih destinasidestinasi tersebut, masyarakat berlatih menjelaskan hal-hal menarik pada tempat tempat tersebut dalam Bahasa Inggris secara mendetail. Sebagai contoh, pada saat mereka berlatih menjadi guide di tempat budidaya anggrek, mereka menjelaskan jenisjenis anggrek yang dibudiayakan, macam-macam warna dan ukuran anggrek, struktur tanaman anggrek, cara perawatan aggrek, cara menanam anggrek, dan cara menyilangkan anggrek. Begitupun pada saat menjelaskan tentang budidaya jamur, masyarakat berlatih menjelaskan tentang jenis-jenis jamur yang bisa dimakan dan yang tidak bisa dimakan, jenis-jenis jamur tiram, jenis-jenis jamur tiram yang dibudidayakan di Desa Mulyorejo, dan juga lima tahapan untuk menumbuhkan jamur tiram yang dimulai dengan pencampuran media, pengukusan, pengisian bibit jamur, inkubasi bibit, dan menunggu jamur tumbuh hingga siap dipanen. Selain itu mereka juga menjelaskan jamur tiram yang dihasilkan bisa diolah menjadi apa saja dan ke mana biasanya jamur dipasarkan. Pada bahasan showing places of interest ini pula dalam pelaksanaannya materi-materi lain seperti explaining rules, explaining safety, explaining etiquette dan closing trip dilatih secara terintegrasi. 


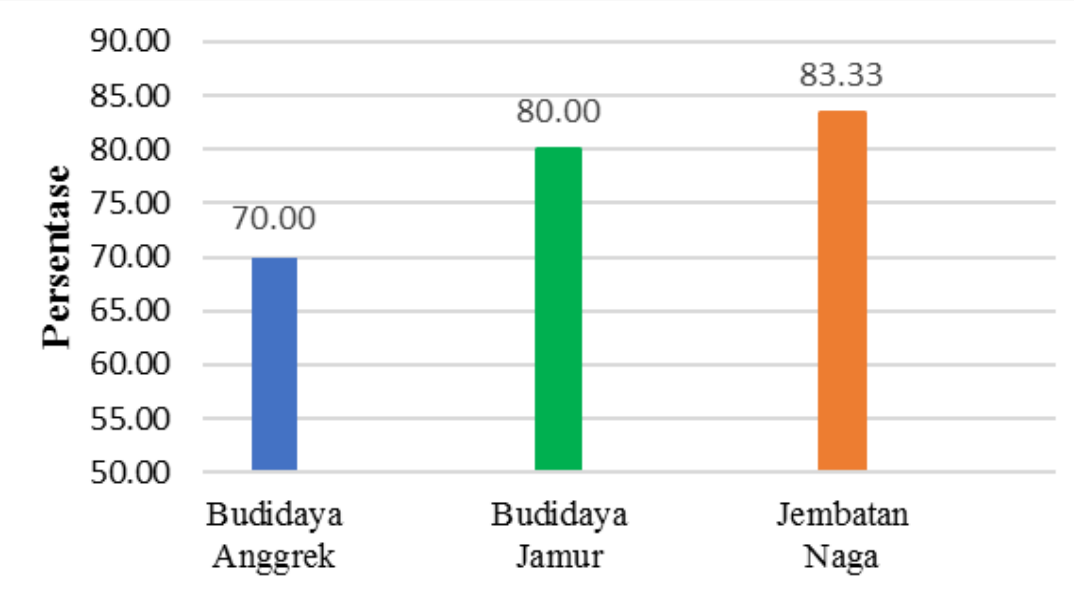

Lokasi Praktek

\section{Gambar 2. Anggota karang taruna yang mampu menyapa turis dan menjelaskan lokasi wisata di tiga destinasi wisata menggunakan Bahasa Inggris.}

Berdasarkan observasi pada saat pelaksanaan pelatihan, kemampuan anggota karang taruna dalam menggunakan Bahasa Inggris untuk menyapa turis dan menjelaskan lokasi wisata dinyatakan dalam Gambar 2. Gambar 2 tersebut menggambarkan bahwa anggota karang taruna yang bisa menjelaskan destinasi wisata budidaya anggrek dalam Bahasa Inggris dengan baik adalah sebanyak 21 orang $(70 \%)$, pada destinasi wisata budidaya jamur sebanyak 24 orang $(80 \%)$, dan pada destinasi wisata lokasi Jembatan Naga sebanyak 25 orang (83.33\%). Persentase-persentase tersebut,kemudian diambil rata-rata dan mendapatkan hasil $77,78 \%$. Setelah membandingkan hasil dengan criteria of success yaitu $75 \%$, maka dapat disimpulkan bahwa program pelatihan English for Guiding telah berhasil.

\section{KESIMPULAN}

Berdasarkan hasil yang diperoleh, bisa disimpulkan bahwa pelaksanaan Program Pengembangan Desa Mitra (PPDM) ini berjalan dengan baik. Hal itu dibuktikan dengan tercapainya criteria of success yang ditetapkan pengabdi. Masyarakat lebih menyadari pentingnya pentingnya pendidikan dan kepariwisataan untuk mengembangkan desa wisata Mulyorejo serta $77,78 \%$ anggota karang taruna yang diberi pelatihan English for Guiding bisa menyapa turis dan menjelaskan lokasi wisata di Desa Mulyorejo dalam Bahasa Inggris. Strategi Yang digunakan pengabdi untuk mencapai kesuksesan tersebut adalah dengan memberikan penyuhan dan pelatihan English for Guiding dengan metode ceramah, drilling, dan praktek lapangan.

\section{SARAN}

Dari pengabdian dalam bentuk penyuluhan dan pelatihan English for Guiding ini, diharapkan masyarakat bisa menerapkan ilmu yang diperoleh untuk lebih memajukan desa wisata Mulyorejo serta bisa menambah pendapatan masyarakat. Di samping itu diharapkan pengurus Karang Taruna mampu membentuk kelompok belajar sehingga ilmu yang telah dipelajari dapat selalu terpakai dan memperkuat kemampuan guiding pemuda Karang Taruna. Pengurus Karang Taruna terakhir juga diharapkan memiliki motivasi yang kuat dalam membangun Karang Tarunanya sehingga Karang Taruna menjadi sumber pemberdayaan pemuda dalam berbagai bidang. 


\section{DAFTAR RUJUKAN}

Fandeli, Chafid. 2002. Perencanaan Kepariwisataan Alam. Fakultas Kehutanan UGM, Yogyakarta.

Hadiwijoyo, Suryo S. 2012. Perencanaan Pariwisata Perdesaan Berbasis Masyarakat (Sebuah Pendekatan Konsep) 1st ed. Yogyakarta: Graha IImu.

http://karya-muda-maron.blogspot.co.id/2015/10/anggaran-dasar-anggaran-rumahtangga.html

http://kedesa.id/id_ID/wiki/pendahuluan/2-lahirnya-uu-no-6-tahun-2014-tentang-desa/ https://id.wikipedia.org/wiki/Mulyorejo,_Ngantang,_Malang

Kurnia, Yudi. 2012. http://www.sapa.or.id//p/116-pjb/1650-pemberdayaan-masyarakatmelalui-pengorganisasian

Kusumaningrum, Dian. 2009. Persepsi Wisatawan Nusantara Terhadap Daya Tarik Wisata Di Kota Palembang. Tesis PS. Magister Kajian Pariwisata. Yogyakarta: Universitas Gadjah Mada.

Latief, M. A. 2012. Research Methods on Language Learning: An Introduction. Malang: UM Press.

Mulyatiningsih, Endang. 2011. Riset Terapan Bidang Pendidikan dan Teknik. Yogyakarta: UNY Press.

Peraturan Menteri Sosial Republik Indonesia Nomor: 77 / Huk / 2010 Tentang Pedoman Dasar Karang Taruna Surat No. 2331/DRPM/TU/2016 tanggal 18 Agustus 2016

Suwantoro, Gamal. 2004. Dasar-dasar Pariwisata. Yogyakarta: Penerbit Andi. 